\title{
Research and Practice of Constructing Engineering Practice Base for Application-oriented Universities
}

\author{
Lihong Han \\ Changchun University of Architecture \& Civil Engineering, changchun, Jilin 130600, China. \\ Project: Subject of the 13th Five-Year Plan of Educational Science in Jilin Province(General Plan) \\ Research on the Cultivation of Practical Ability of Engineering Cost Majors in Application-oriented Private Universities \\ under the Information Situation of Construction Industry \\ Subject No. GH180456

\begin{abstract}
Practical training" is very important in construction engineering, especially for the construction engineering major of application-oriented undergraduate colleges. For students to master professional knowledge, it is necessary to carry out effective practical teaching. Generally speaking, teachers carry out practical training at the practical training base. Therefore, college leaders and teachers have always been very concerned about the construction of training bases. This article analyzes the construction of the construction engineering training base focusing on how to build a practical training base in application-oriented undergraduate colleges, in order to train more construction engineering professionals to meet the needs of social development.
\end{abstract}

Keywords: Applied Undergraduate; Construction Engineering; Practical Training Base; Construction Research

With the continuous improvement of China's comprehensive national strength, the development scale of the construction engineering industry is growing stronger and the demand for professional talents is becoming more and more urgent. Application-oriented undergraduate colleges are important institutions for cultivating construction engineering professionals in China. In order to better meet the needs of social development for construction engineering professionals, many application-oriented undergraduate colleges are actively exploring talent training programs in the new era. Among them, strengthening students' "practical ability" is the focus of the teaching reform of architectural engineering. To improve students' practical ability, the construction of a professional training base for construction engineering is inseparable. At present, there are still many deficiencies in the construction of training bases for construction engineering majors in some colleges and universities. This has affected the cultivation of construction engineering talents to a certain extent and needs to be highly valued by school leaders and teachers.

\section{Analysis of the current situation of the construction of practical training bases for Constructing Engineering majors in application-oriented undergraduate colleges}

\subsection{The training content of the training base has not been updated with the times}

"Training teaching" is mainly to cultivate students' practical ability, and the construction of the training base should fully meet the needs of practical teaching. However, some colleges and universities have practical training bases with limited available teaching tools and inadequate construction engineering equipment. The training programs organized by teachers are unqualified that they do not integrate with the development of society and timely incorporate new content. Such practical teaching not only fails to cultivate students' practical ability, but also makes students feel tired and lose

Copyright (C) 2020 Lihong Han

doi: 10.18282/le.v9i5.1262

This is an open-access article distributed under the terms of the Creative Commons Attribution Non-Commercial License

(http://creativecommons.org/licenses/by-nc/4.0/), which permits unrestricted non-commercial use, distribution, and reproduction in any medium, provided the original work is properly cited. 
interest in practical learning.

\subsection{The school-enterprise cooperation relationship in the training base is unstable and unsound}

Some colleges and universities practice cooperation with enterprises. Such school-enterprise cooperation should be a "win-win" situation, which can not only provide better practical learning content for students, but also provide some high-quality professional talents to enterprises. However, in actual situations, the training base for cooperation with enterprises is usually very incompatible. This kind of incompatibility mainly comes from two aspects: on the one hand, the enterprise has not solved its own talent demand in the school-enterprise cooperation mechanism. On the contrary, it has invested a lot of manpower and material resources, which makes the enterprise lack the motivation to continue the cooperation. On the other hand, the training base for construction engineering majors often transfers along with the enterprise's engineering projects. In the connection between one engineering project and another engineering project, there is usually an "empty period". At this time, the enterprise can only stop cooperating with the school.

\subsection{The teaching in the training base does not focus on combining theory with practice}

The main teaching task of the practical training base is to carry out practical teaching and cultivate students' practical ability, but the cultivation of practical ability can not only be strengthened by the practice stage, but should also combine theory with practice. In the construction of training bases in some colleges and universities, there is a deviation in the overall instructional design, which splits theoretical learning and practical learning, which is reflected in the following aspects: First, before the start of teaching in the training base, teachers did not carry out the necessary pre-training work. Therefore, students do not have any understanding of the upcoming training projects, which will lead to students' learning direction is not clear in the training base and their efficiency is not high. Second, in the training base, the teacher did not include the explanation of knowledge, which makes it easy for students to fall into a "handingon without thinking" learning state, which is not conducive to students' understanding of the connotation of practical projects. Third, after the end of teaching at the training base, students encounter problems and doubts. Some teachers in colleges and universities did not answer questions in the classroom, and did not consolidate the knowledge points encountered by students in practical learning, resulting in more problems that students do not understand.

\section{Construction strategy of the practical training base for Constructing Engineering specialty in applied undergraduate colleges}

\subsection{Update the training content of the training base with the times}

In order for the training base to fully play its role and cultivate more professionals with practical ability, universities should update the training content of the training base with the times. To be more concise, on the one hand, colleges and universities should update the training equipment and tools of the training base so that students can learn the professional knowledge of the construction engineering industry in a better teaching environment and learn about the latest equipment in the construction engineering industry, so that students can skillfully operate related equipment and instruments in specific work in the future. On the other hand, colleges and universities should update the training content of the training base with the times, in the existing training cases and reasonably add new content.

\subsection{Build a stable school-enterprise cooperation relationship}

In recent years, during the construction of college training bases, the problem of unstable cooperation between schools and enterprises in training bases has become increasingly prominent, which has caused serious obstacles to the cultivation of students' practical ability. In order to build a stable cooperative relationship between schools and enterprises in practical training bases, on the one hand, in the process of establishing the school-enterprise cooperation mechanism, the school must fully consider the requirements of the enterprise, and the enterprise must also fully consider the demands of the school that the two sides must reach a consensus. At present, some companies are willing to accept school-enterprise cooperation not because of their subjective will, but because of the influence of a variety of realistic factors. Such a negatively maintained school-enterprise cooperation mechanism is difficult to ensure the effectiveness of students' practical learning. In order to build a stable school-enterprise cooperation mechanism, the school should think 
from the perspective of the enterprise, analyze the problems existing in the development of the enterprise, and strive to solve some of the concerns and difficulties of the enterprise through the school-enterprise cooperation. In this way, the school-enterprise cooperation mechanism will be more stable. On the other hand, considering that the companies in the training base are often affected by engineering projects, to carry out irregular transfers, colleges and universities need more communication and early prediction, and establish long-term school-enterprise partnerships, to ensure that the optimal allocation of resources is flexibly realized as much as possible before the "empty period" happens, and stable practical learning opportunities are created for students.

\subsection{The teaching of practice bases should focus on combining theory with practice}

As China's construction engineering industry increasingly needs talents, the construction of college training bases must pay close attention to students' learning effectiveness. To improve students' learning effectiveness at the training base, it is not possible to separate theoretical knowledge from practical knowledge, and it is a must to focus on combining theory with practice. First, when the training base is about to be launched, teachers should give students relevant training and pre-training, so that students can roughly understand the direction and main content of practical training. Second, students learn at the training base At the time, for each practical operation, the teacher should give professional guidance related to it, and they can't ignore the students and let the students practice casually. Third, considering that each student's actual acceptance ability is different, at the end of each training session, teachers should pay attention to the "answering questions" section to help students solve various problems encountered in the training and learning.

\section{Conclusion}

When learning relevant knowledge of construction engineering, training students' practical ability and improving students' practical ability are inseparable from the practical teaching of the practical training base. Therefore, colleges and universities should attach importance to the construction of a training base for construction engineering majors, that is, to strengthen the practical training of the training base in order to train more practical professionals. In the future, with the continuous development of China's construction engineering industry, there will be higher requirements for the "quantity" and "quality" of talents. As a college educator in the new era, in addition to the "practical ability" as the teaching goal, the construction engineering talent training model should also consciously stimulate students' innovative thinking so that students can achieve the learning effect of "drawing inferences about other cases from one instance", to better pursue the rapid development of the construction engineering industry.

\section{References}

1. Zhang L. Exploration and practice of the construction and operation of comprehensive training bases for Construction Engineering specialty in secondary vocational schools. Fujian Building Materials 2019; (02): 116-118+115.

2. Chen S. Research on the construction model of the comprehensive training base for the Construction Engineering specialty of vocational schools. Fujian Building Materials 2018; (07): 117-118+49.

3. $\mathrm{Wu} \mathrm{C}$. Research on the construction of higher vocational training bases under the modern apprenticeship. Modern Economic Information 2018; (10): 463. 